\title{
Investigation into First-Year College Students' Misconceptions about Limit Concept: A Case Study Based on Cognitive Style
}

\author{
Kamid, Khairul Anwar", Syaiful, Sofnidar, Lita Liani, Wawan Kurniawan \\ Faculty of Teacher Training and Education, Jambi University, Indonesia
}

Received January 13, 2020; Revised February 26, 2020; Accepted March 12, 2020

Copyright $\odot 2020$ by authors, all rights reserved. Authors agree that this article remains permanently open access under the terms of the Creative Commons Attribution License 4.0 International License

\begin{abstract}
The cognitive style has an important role in determining the characteristics of students on the conceptualization. One of the two types of cognitive styles are field independent (FI) and field dependent (FD). The purpose of this study was to identify the form of conceptual misconceptions about limit and their causes. This type of research is a case study. The data was obtained through interviews based on the conceptual problem-solving tasks. Correspondents used in this study were from first-year college students (95 people) who were studied at Universitas Jambi. The results showed that (1) FI forms of students' misconceptions, namely: misconceptions about interpreting the concept of function limit and function conditions which have limits, such as: left limit and right limit. This problem occurred due to incomplete reasoning and wrong intuition. The other result of this research was to obtain (2) FD forms of students' misconception, namely, (a) misconceptions about prerequisite material: drawing graphs of functions, misconceptions about determining the domain of a function, misconceptions about definitions and forms of function notations, misconceptions about determining function values on function graphs (b) misconceptions about the concept of limits: misconceptions about interpreting the concept of limits in a function, the function requirements (left limit, right limit) and misconceptions about understanding the meaning which is close to the limit function (limit-x) approaching infinity.
\end{abstract}

Keywords Cognitive Style, Field Independent and Field Dependent, Limit Concept, Misconceptions, Mathematics Education

\section{Introduction}

Mathematics is the science of logic regarding form, structure, quantity, and concepts that interconnected between one to another. Thus, one of the competencies needed by students in mastering mathematics is a deep understanding of mathematical concepts. The theory of constructivism stated that students have to find and transform complex information, check new information with old rules, and revise them if the rules are no longer appropriate by themselves [1]. The theory was the bas is of learning activities. It also emphasized the fact that if students do a cognitive process, it will fulfill students' cognition in the form of structuring concepts from the learning environment delivered by the teacher. When students constructed a concept understanding in the cognitive structure which was obtained from interactions with the learning environment, it would highly produce errors in interpreting concepts. Mistakes in interpreting mathematical concepts are often called misconceptions [2]

Misconception was referred to a concept that was not followed by a scientific understanding or expert agreement in the field [3]. Furthermore, [4] and [5] defined misconception as a cognitive structure in the form of a strong understanding that was different from what should be according to scientific principles in general. Besides, it would disturbed the acceptance of new understandings. Misconceptions in understanding mathematical concepts have been found in many studies [5], [6], [15], [16], [7][14].

First-year college student need to adapt to entering university level [17]-[23]. Usually, they still carry the previous concept of learning, namely, high school level [18]. Early detection related to misconceptions could facilitate teachers to provide appropriate learning instructions. Limit concept underlay all concepts in 
calculus, thus it made limit become extremely fundamental in this learning [5]. If not properly being prepared, then limit concept could be difficult to be understood in calcu lus [24].

Specifically, a misconception about the limit concept has been carried out by [5] for secondary school level. They also explained how cognitive style affects the misconceptions. Misconceptions would occurred when students received information about a concept. Each students has a unique way or fondness in obtaining, organizing information (cognition) and processing information (conceptualization), which we usually called cognitive style [25]-[30]. Thus, it could be presumed that the cognitive style would play an important role in making students' misconceptions. The research had the same results with Lawson \& Thompson (1988) who mentioned that one of the factors which caused students' misconceptions was the field-independent (FI) and field-dependent (FD) cognitive styles.

\section{Method}

\subsection{Research Design}

This study identified forms of misconceptions about the limit concept in first-year college students based on their cognitive style. Therefore, this research used a qualitative paradigm with a case study approaching.

\subsection{Subject Research}

This research was conducted in The Mathematics Education Study Program in Universitas Jambi. The research subjects were first-year college students (95 people) who took calculus course by considering the following reasons for research subjects selection: (1) registered first-year college students who had to take calculus courses, (2) first-year college students who had a cognitive style of FI and FD, (3) first-year college students who had misconceptions about the concept of limit based on the Certainty of Response Index (CRI) category with CRI value $>2.5$ and wrong answer category, but high CRI value, which could be interpreted as experiencing misconception.

\subsection{Data Collection}

The data collection is through a pretest before learning is carried out. This means that students' knowledge of the concept of limits is inherited from high school. Research data collection was carried out by the following stages: (1) A diagnostic was conducted through a multiple Certainty of Response Index (CRI) test. The aim of the test was to obtain data on students experiencing misconceptions [4]. (2) Cognitive style tests that using GEFT was carried out [30], [32] to determine the type of congressional style of research subjects based on CRI tests that were distinguished based on cognitive style. (3) After finding the research subject that experienced misconceptions based on the clasification of the positive force, then the limit concept understanding test would be performed in the form of an essay test (as example in Figure 1). Based on the results of the third stage of the test, further identification of the form of misconception was carried out. (4) The forms of misconception from the concept understanding test were also explored to find out the forms and causes of misconceptions that occurred, through semi-structural interviews and video records. This activity was a form of data triangulation aimed at testing the validity and reliability of the data that had been obtained.

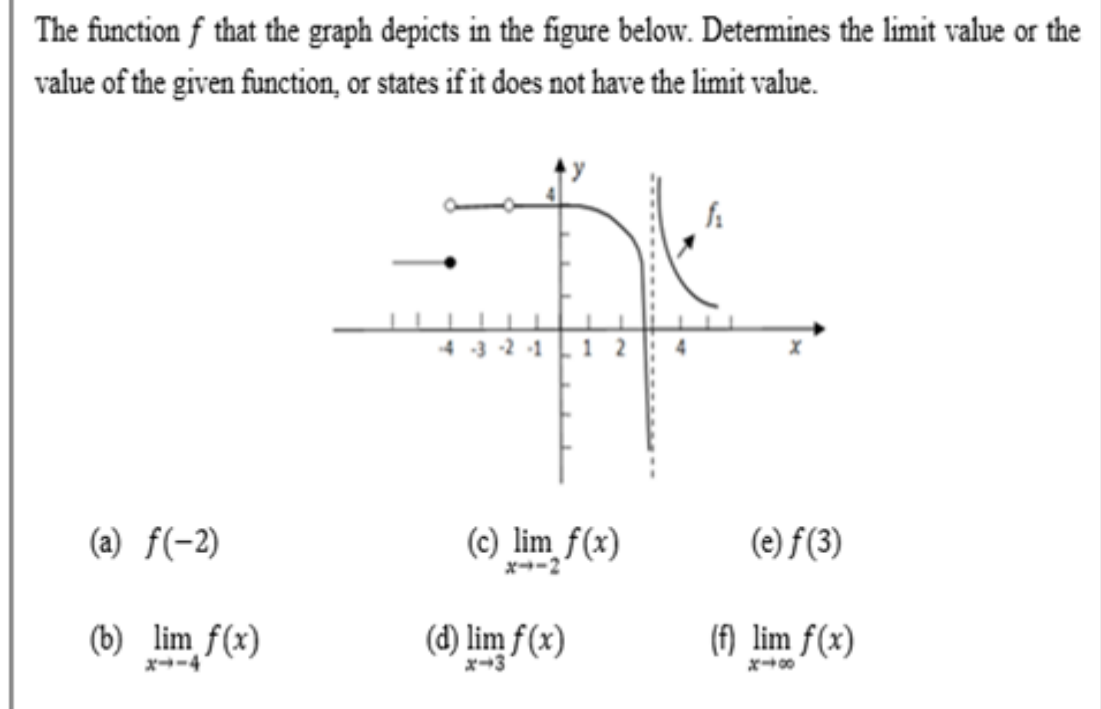

Figure 1. Problem about underst anding the concept of limit 


\subsection{Data Analysis}

The data consisted of: (1) misconception classification tests using CRI TEST. The misconception criteria adopted from [33] are explained in Table 1 as follows.

Table 1. Criteria of Misconceptions

\begin{tabular}{|l|l|l|}
\hline Answer Criteria & \multicolumn{1}{|c|}{ Low CRI Value $(<\mathbf{2 , 5})$} & \multicolumn{1}{c|}{ High CRI Value $(>\mathbf{2 , 5 )}$} \\
\hline Correct answer & $\begin{array}{l}\text { The answer is correct, but the CRI value is low, } \\
\text { meaning it doesn't know the concept (Lucky guess) }\end{array}$ & $\begin{array}{l}\text { Correct answer and high CRI value mean mastering the } \\
\text { concept well. }\end{array}$ \\
\hline Incorrect answer & $\begin{array}{l}\text { Wrong answers and low CRI values mean it doesn't } \\
\text { knowthe concept. }\end{array}$ & Incorrect answer but high CRI value mean misconception. \\
\hline
\end{tabular}

The CRI scores in Table 1 were taken from the average CRI scores for every student. There were groups of students who knew the concept (TK), did not know the concept (TTK) and those who had misconceptions (MK); (2) data from the interview activity was recorded and then mapped based on the misconception indicator code to the concept of limit, as shown in Table 2 below.

Table 2. Indicator of Concept Limit

\begin{tabular}{|l|l|}
\hline Domain Concept & \multicolumn{1}{|c|}{ Indicator } \\
\hline \multirow{4}{*}{$\begin{array}{l}\text { The concept of prerequisite limit of } \\
\text { functions }\end{array}$} & Understanding the definition of a function \\
\cline { 2 - 3 } & Understanding the meaning of notation in a function \\
\cline { 2 - 3 } & Drawing a graph of a function \\
\cline { 2 - 3 } & Determining the value of a function \\
\cline { 2 - 3 } & Determining the area of origin of a function. \\
\cline { 2 - 3 } & Determining the result area of a function. \\
\hline \multirow{5}{*}{ The concept of limit of functions } & Understanding the definition a limit of function \\
\cline { 2 - 3 } & Understanding the meaning of notation in the limit of functiona \\
\cline { 2 - 3 } & Understanding the meaning "close" to the limit of function \\
\cline { 2 - 3 } & Determining the right limit of a function \\
\cline { 2 - 3 } & Determining the left limit of a function \\
\cline { 2 - 3 } & Understanding the properties continuity of a function \\
\cline { 2 - 3 } & Determining the conditions for the existence a limit of function \\
\cline { 2 - 3 } & Determining the value limit of function \\
\hline
\end{tabular}

\section{Research Result}

\subsection{Forms of Misconception about the Concept of Limit Experienced by FI Students}

\subsubsection{Misconception about Understanding the Concept Definition of the Limit on a Function}

We know that the formal definition of a $\lim _{x \rightarrow r} f(x)=L$, is function $f$ approaches the limit $L$ as $x$ approaches $c$. thinking about limits is related to the behavior of a function near $\mathrm{c}$ not at $\mathrm{c}$. And the function $\mathrm{f}$ does not require to be defined in c [34]. FI students understood the concept of $\lim _{x \rightarrow c} f(x)=L$, as $x$ approached $c$, the value of $x$ did not approach to $c$. Then, misconceptions occured when understanding the value of $L$, where subjects understood that the value of $\mathrm{L}$ is right at $f(x)$ and required the function $f$ to be defined in $\mathrm{c}$. 
Table 3. Misconceptions in interpreting the concept of limit on a function

\begin{tabular}{|l|l|}
\hline Questions & Student's Answers \\
\hline $\begin{array}{l}\text { Explain the definition of } \\
\lim _{\boldsymbol{x}-\boldsymbol{c}} \boldsymbol{f}(\boldsymbol{x})=\boldsymbol{L}\end{array}$ & $\begin{array}{l}\text { Student : So, The Function of limit is limit } \mathrm{f}(\mathrm{x}) \text { as } x \text { approaches } c \text {, then } f(x)=L \\
\text { Teacher: Furthermore, if } x \text { approaches } 1 \text {, is it very close to } 1 \text { or equal to } 1 \text { ? } \\
\text { Student : I think Sir, limit } f(x) \text { is not equal to } 1 \text { as } x \text { approaches } 1 . . \\
\text { Teacher: How about the value } f(x)=L \text {, is the value exact } L \text { or close to } L \\
\text { Student : Yes, same as } L \text { (exact) }\end{array}$ \\
\hline $\begin{array}{c}\text { Student FI considers that the "empty sphere" on the graph he made states that it has no limits. It can be seen } \\
\text { from the following graph function made by Student FI. }\end{array}$ \\
$\begin{array}{c}\text { Analysis of } \\
\text { base on the left and } \\
\text { right-hand limits }\end{array}$ & \\
&
\end{tabular}

FI students understood that the value of left limit was the same as the right limit, which was 1 , but due to an empty circle at the graph function, $\lim _{x \rightarrow 1} f(x)$ did not have a limit value. So, it could be interpreted that FI students' understanding of $\lim _{x \rightarrow c} f(x)=L$, required a value in $f(x)$, or in other words, the value of $\mathrm{L}$ was exact on $f(x)$.

\subsubsection{Determining the Conditions for the Existence a} Limit of Function (Left and Right-Hand Limit)

Table 4. Misconceptions about understanding the properties of functions that had limit

\begin{tabular}{|c|c|}
\hline Questions & Student's Answers \\
\hline $\begin{array}{l}\text { Determine the } \\
\text { limit value of } \\
\lim _{x \rightarrow-4} f(x) \\
\text { or state if it does } \\
\text { not have the limit } \\
\text { value. }\end{array}$ & $\begin{array}{l}\text { Teacher: Why is limit } x \text { close to }-4 \text {, does } \\
\text { the limit value not exist? } \\
\text { Student: Yes, the right limit does not have a } \\
\text { limit, because the circle is empty here. Limit } \\
\mathrm{x} \text { approaches }-4=f(4) \text {, so the value } \\
f(-4) \text { does not exist because the circle is } \\
\text { empty.(see the question picture) }\end{array}$ \\
\hline
\end{tabular}

FI students understood that the requirements of a limit function that has a limit were correct if the left limit and right limit were the same. Misconceptions occured about understanding left or right function limits that we undefined as $x=c$ (blank round). FI students understood that functions did not have limit. To find out the misconceptions that occured in FI students, researchers provide questions as seen in Table 4.

Student FI stated that the right limit has no limit value, because $\lim _{x \rightarrow c} f(x)=f(c)$, while $f(c)=f(-4)$ does not exist or is an empty circle in the graph function.

\subsubsection{Understanding the Meaning "Close" to the Limit of Function}

The misconception that occurred in the next FI student was interpreting the close meaning of a function. Students understood that in an empty circle, $f(x)$ is undefined when $x=c$, and then it would define that the function has no limits. In question number 2 part " $c$ ", limit $f(x)$ when $x$ approaches -2 , students answered "its limit does not exist" for the reason that the left limit and right limit are the same (found). But because $f(-2)$ is an empty round, then the limit does not exist. So based on the previous description, it can be interpreted that FI students understand that a limit must be exact when $x=c, f(c)$ exists. The concept of a limit that uses language approaches, does not have to be right at $x=c$ not owened by FI student. 
Table 5. Understanding the meaning "close" to the limit of function

\begin{tabular}{|c|c|}
\hline Questions & Stu dent's Answers \\
\hline $\begin{array}{l}\text { Determine limit value of } \lim _{x \rightarrow-2} f(x) \\
\text { or state if it does not have the limit value. }\end{array}$ & $\begin{array}{l}\text { Teacher: Why } \lim _{x \rightarrow-2} f(x) \text { does not have a limit? } \\
\text { Student: The limit does not exist because the circle is empty, but has the left } \\
\text { and right limits. }\end{array}$ \\
\hline Determine limit value of $\lim _{x \rightarrow \infty} f(x)$ & $\begin{array}{l}\text { Teacher: Why } \lim _{x \rightarrow \infty} f(x) \text { does not have a limit? } \\
\qquad 9) \lim \in(0)=t \text { dak a dox } \\
\text { Student: Because I don't know where it ends }\end{array}$ \\
\hline
\end{tabular}

FI students stated that there was no limit approaching infinity because they did not know where it ends.

\subsection{Forms of Misconception about the Concept of Limits Experienced by FD Students}

\subsubsection{Misconception about Sketching Function Graphs}

Misconceptions that occurred in FD students was found in sketching graphs of functions. Students understood that in drawing a graph of a conditional function, the closed and opened intervals at the intervals/limits of a given function did not affect (continuous and non-continuous functions at $x=c$ ) the graph functions. This could be seen in the sketch that drawn by FD students as follows,

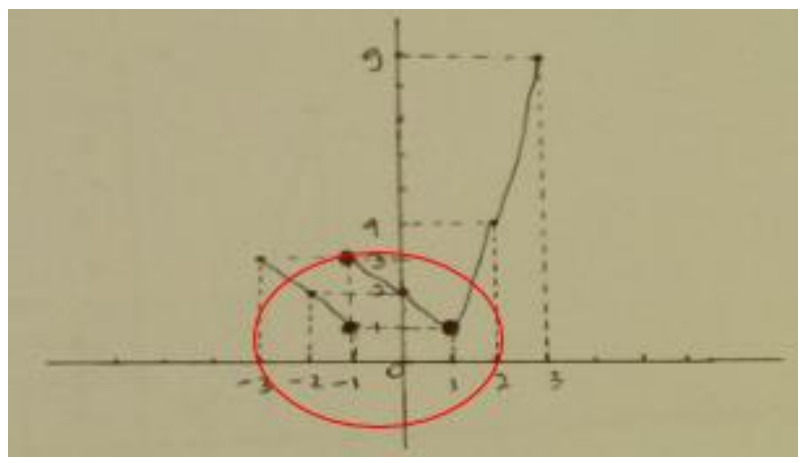

Figure 2. Sketch of a function graph by FD students

\subsubsection{Misconception about Understanding the Concept} Definition of the Limit on a Function

The researcher asked the FD students about both of their knowledge or their understanding about the concept definition of the limit on a function. The FD students replied that the function is like a sequence. The value of $\mathrm{L}$ is the limit or the limit value. Like a sequence, if there is no limit the sequence has no limit. The students' statement could be seen in Table 6 .

Table 6. Misconception about understanding the concept definition of the limit on a function

\begin{tabular}{|l|l|}
\hline Questions & Student's Answers \\
\hline \multirow{2}{*}{$\begin{array}{l}\text { Define } \\
\lim _{x \rightarrow c} \boldsymbol{f}(\boldsymbol{x})=\end{array}$} & $\begin{array}{l}\text { Teacher: } \\
\text { understand } \lim _{x \rightarrow c} f(x)=L ? \\
\text { Student : This states that the value (L) of the } \\
\text { limit of a function } \mathrm{f}(\mathrm{x}) \text { when } \mathrm{x} \text { approaches c } \\
\text { Teacher: Explain what is your understand about } \\
\text { the value of } \mathrm{L} \\
\text { Student : The value of L is the limit or the limit } \\
\text { value. Like a sequence, if there is no limit the } \\
\text { sequence has no limit. }\end{array}$ \\
\hline
\end{tabular}

3.2.3. The Misconception about Determining the Function Value of a Function Graph

In determining the function value of a function graph, FD students experienced misconceptions about determining the function value of a function that had an asymptote line. Students understood that the asymptote line was the value of a function. Misconceptions could be seen from the answer sheet FD in question number 2 part "e". FD students answered that the value of $f(3)$ was 3 . Based on the interview in Table 7, it appeared that FD students understood that the asymptote line was $\mathrm{x}=\mathrm{c}$, $\operatorname{sof}(\mathrm{x})=\mathrm{c}$. 
Table 7. The misconception about determining the function value of a function graph

\begin{tabular}{|l|l|}
\hline Questions & Student's Answers \\
\hline Teacher: Why is your answer $f(3)=3$ ? \\
Student : Actually I'm confused, but my feeling is the dot ted line at 3, so I answered
\end{tabular}

Table 8. Determination of the conditions for the existence a limit function (left and right-hand limits)

\begin{tabular}{|l|c|}
\hline \multicolumn{1}{|c|}{ Questions } & Student's Answers \\
\hline $\begin{array}{l}\text { Tetermine the limit value of } \lim _{x \rightarrow-4} \boldsymbol{f}(\boldsymbol{x}) \\
\text { or state if it does not have the limit value }\end{array}$ & Student : Because there is a full circle, that is $\mathrm{f}(-4)=2$ \\
\hline
\end{tabular}

Then the researchers assumed if at $\mathrm{f}(\mathrm{x}), \mathrm{x}$ would approached -4 from the right limit with a full round whether the limit had a value, and then the FD students answered no value for it. The researcher asked the value of limit $\mathrm{f}(\mathrm{x})$, when $\mathrm{x}$ approached -4 , and FD1 replied 2 and 4.

\section{Discussion, Conclusions and Suggestion}

This study discusses the forms of misconceptions experienced by FD and FI students about understanding the concept of limit functions. [35] stated that it was not enough to know only about the misconceptions, but it must be understood in detail and strategies were needed to solve it. Based on the results, FD students experienced misconceptions starting from the learning materials delivery from the the teachers in learning activities. FD students experienced not only misconceptions of concept of limits, but also misconceptions about the prerequisite concept, such as: sketching graphs of functions. [36] stated that individual knowledge, related to understanding the problem situation, would cause variations in mental models that were formed and were constructed. The misconceptions stemmed from a wrong understanding of a concept. Sche ma Cognitive structure that has been formed into an understanding would continue to be used in the formation of further cognitive structure schemes.

The term cognitive was used to refer the processes that occured in the individual brain, which assisted in the process, manipulation, storing, and retrieving information about the outside world [37]. Piaget in [38] also explained that schemata (schemas) were a cognitive structure. An individual could bind, understood, and responded to a stimulus due to the operation of this scheme. In other words, cognitive skills were the processes or skills that could help us think, solve problems, collaborate, and create schemes.

Incorrect understanding of the concept of prerequisites for FD students made an understanding scheme. When an external stimulus (new matrices schemes) was given, FD students would tend to assimilate it. Assimilation is the process of directly integrating new stimu li into established schemes [38], which means that FD students do not modify the schemes they have. For example, FD students understand the value of a function in $\mathrm{c}$ or $\mathrm{f}(\mathrm{c})$, and there is a new concept that is given that is the limit of infinite 
functions. The understanding of the concept of infinite functions formed into misconceptions in which FD students tended to assimilate the prior knowledge schemes that they had before, namely the concept of function values. FD students understood that $\lim _{x \rightarrow \infty} f(x)$ then the function had no limit, and students assumed that the limit existed if the function was defined $x=c$. Misconceptions of FD students occurred because they were confused about the term "close" to the function limit. [39] stated that the delivery of ideas (ways of conveying concepts) from the teacher in learning that was beyond the ability of students' thinking could cause misconceptions about understanding the concept of limits. This is an important factor for teachers to know what students abilities and characteristics are in learning

The characteristics of FD students who tended to be influenced by complex contexts and tended to view a concept as a whole made acceptance of student concepts became unobstructed, so that understanding concepts could form misinterpretation because of the limitations of the appropriate concept structure. For example, one of the causes of FD students' misconceptions was the students' cognitive style, which occurred in the concept of the definition of the limit function. FD students understood that $\lim _{x \rightarrow c} f(x)=L$, required using limits, and if there were no restrictions, then it was infinite and had no limit on that function. This indicated that in the understanding of a complex nature, cognitive style influenced students on understanding the concept of "close" to the limit, thus causing misconceptions.

Misconceptions about the function limit concept also occurred in FI students. However, misconceptions about prerequisite material did not occur in FI students, and it appeared due to incomplete reasoning and wrong intuition [31]. It is possible to happen because the FI students tend to be good at understanding complex concepts. As exp lained by [30], FI students were not easily fooled by elements that were not relevant to the context. They also could determine the part - simple parts separate from the original context.

With the understanding of teachers related to detecting and preventing misconceptions, it was expected to minimize the occurrence of misconceptions in students. [40] stated that teachers would be able to arrange their instructions if they knew possible misunderstandings and misconceptions that students might have. Misconceptions could be minimized by providing visual displays and animations when learning limit functions [41]. However, [5] stated that the use of single animation might not be effective, because an explanation should be given while using it. Visual learning method alone was not sufficient in developing the concept of limits.

\section{REFERENCES}

[1] Trianto, Model-model pembelajaran Inovatif Berorientasi Konstruktivistik. Jakarta: Prestasi Pustaka, 20017.
[2] I. Zembat, "Misconceptions What is it?" in Mathematical Misconceptions and Solutions, A. H. (eds) Özmantar MF, Bingölbali M, Ed. New York: PegemA Publishing, 2008, pp. $1-8$.

[3] P. Suparno, Miskonsepsi \& Perubahan Konsep dalam Pendidikan Fisika. Jakrta: Grasindo, 2015.

[4] S. Hasan, D. Bagayoko, and E. L. Kelley, "Misconceptions and the Certainty of Response Index (CRI)," Phys. Educ., 1999.

[5] S. Kula and E. B. Güzel, "Misconceptions emerging in mathematics student teachers' limit instruction and their reflections," Qual. Quant., vol. 48, no. 6, pp. 3355-3372, 2014.

[6] M. Swan, "Dealing with misconceptions in mathematics," Issues Math. Teach. London, 2001.

[7] C. R. Rakes, "Misconceptions in rational numbers, probability, algebra, and geometry.," 2011.

[8] T. Kabaca, Z. Karadag, and M. Aktumen, "Misconception, cognitive conflict and conceptual changes in geometry: A case study with pre-service teachers.pdf," Meviana Int. J. Educ., 2011.

[9] A. J. Stylianides, "Towards a comprehensive knowledge package for teaching proof: A focus on the misconception that empirical arguments are proofs,"Pythagoras, 2011.

[10] E. M. Ozkan and A. Ozkan, "Misconception in Exponential Numbers in IST and IIND Level Primary School Mathematics,"Procedia - Soc. Behav. Sci., 2012.

[11] O. Koklu and A. Topcu, "Effect of Cabri-assisted instruction on secondary school students' misconceptions about graphs of quadratic functions," Int. J. Math. Educ. Sci. Technol., 2012.

[12] E. A. R. Pinahayu, "Problematika Pembelajaran Matematika pada Pokok Bahasan Eksponen dan Alternatif Pemecahannya," Form. J. Ilm. Pendidik. MIPA, 2016.

[13] V. Trivena, A. R. Ningsih, and A. Jupri, "Misconception on Addition and Subtraction of Fraction at Primary School Students in Fifth-Grade," in Journal of Physics: Conference Series, 2017.

[14] P. Potvin, S. Masson, S. Lafortune, and G. Cyr, "PERSISTENCE OF THE INTUITIVE CONCEPTION THAT HEAVIER OBJECTS SINK MORE: A REACTION TIME STUDY WITH DIFFERENT LEVELS OF INTERFERENCE,” Int. J. Sci. Math. Educ., 2014.

[15] L. H. Ang and M. Shahrill, "Identifying Students' Specific Misconceptions in Learning Probability," Int. J. Probab. Stat., 2014.

[16] M. F. Öçal, “Asymptote Misconception on Graphing Functions: Does Graphing Software Resolve It?" Malay sia Online J. Educ. Techology, 2016.

[17] A. I. Clinciu, "Adaptation and Stress for the First Year University Students," Procedia - Soc. Behav. Sci., 2013.

[18] D. J. Hermida, "The Importance of Teaching Academic Reading Skills in First-Year University Courses," SSRN Electron. J., 2011.

[19] S. Hurtado, D. F. Carter, and A. Spuler, "Latino student 
transition to college: Assessing Difficulties and Factors in Successful College Adjustment," Res. High. Educ., 1996.

[20] K. K. Inkelas, Z. E. Daver, K. E. Vogt, and J. B. Leonard, "Living-learning programs and first-generation college students' academic and social transition to college," Res. High. Educ., 2007.

[21] R. D. Reason, P. T. Terenzini, and R. J. Domingo, "First things first: Developing academic competence in the first year of college,” Res. High. Educ., 2006.

[22] D. Tenofsky and B. Macke, "Challenging and Supporting the First-Year Student: A Handbook for Improving the First Year of College (review)," portal Libr. Acad., 2005.

[23] V. Tinto, "Taking Retention Seriously: Rethinking the First Year of College," NACADA J., 1999.

[24] J. E. Szydlik, "Mathematical beliefs and conceptual understanding of the limit of a function," J. Res. Math. Educ., 2000.

[25] R. Borromeo Ferri, "On the Influence of Mathematical Thinking Styles on Learners' Modeling Behavior," J. fur Math., 2010.

[26] E. Cools and H. Van Den Broeck, "Development and validation of the cognitive style indicator," J. Psychol. Interdiscip. Appl., 2007.

[27] E. R. Peterson, S. G. Rayner, and S. J. Armstrong, "Researching the psychology of cognitive style and learning style: Is there really a future?" Learn. Individ. Differ., 2009.

[28] S. G. Rayner, "Cognitive Styles and Learning Styles," in International Encyclopedia of the Social \& Behavioral Sciences: Second Edition, 2015.

[29] E. Sadler-Smith, "The relationship between learning style and cognitive style,” Pers. Individ. Dif., 2001.

[30] H. A. Witkin, C. A. Moore, D. Goodenough, and P. W. Cox, "Field-Dependent and Field-Independent Cognitive Styles and Their Educational Implications," Rev. Educ. Res. 1977.

[31] A. E. Lawson and L. D. Thompson, "Formal reasoning ability and misconceptions concerning genetics and natural selection," J. Res. Sci. Teach., vol. 25, no. 9, pp. 733-746, 1988.

[32] M. Khatib and R. M. Hosseinpur, "On the Validity of the Group Embedded Figure Test (GEFT),” J. Lang. Teach. Res., 2011.

[33] S. Hasan, D. Bagayoko, and E. L. Kelley, "Misconceptions and the Certainty of Response Index (CRI)," Phys. Educ., vol. 34, no. 5, pp. 294-299, 1999.

[34] D. Tall and W. Kaplan, “Advanced Calculus,” Math. Gaz., 1985.

[35] S. Sandır, H., Aztekin, "Pre-service teachers' opinions and methods about finding students' misconceptions,"M Mediterr. J. Math., vol. 12, pp. 23-37, 2013.

[36] W. E. Glenberg, A. M., Kruley, P., \& Langston, “Analogical pro- cesses in comprehension: Simulation of a mental model.," in Handbook of psy cholingu istics, M. A. G. (Ed.),
Ed. San Diego: A: Academic Press., 1994,pp.609-640.

[37] K. dan Brown, BrainWare Safari: Cognitive Skills Development and Learning to Read. Chicago: Learning Enhancement Corporation, 2004.

[38] U. Suherman, E dan Winataputra, Materi Pokok Strategi Belajar Mengajar Matematika. Jakarta: Universitas Terbuka, Departemen Pendidikan dan Kebudayaans, 1993.

[39] H. Cinvestav, F.H., Chavez, "Limits, Continuity and Discontinuity of Functions from Two Points of View: That of the Teacher and That of the Student," in Proceedings of theBritish Society forResearch into Learning Mathematics, 1999.

[40] K. Grouws, D., Schultz, "Mathematics teacher education," in Handbook of Research on Teacher Education 2nd, J. (ed. Sikula, Ed. New York, 1996.

[41] I. Kidron and N. Zehavi, "The Role of Animation in Teaching the Limit Concept.," Int. J. Comput. Algebr. Math. Educ., 2002. 